\title{
THE ARTIST'S REALITY
}


This page intentionally left blank 


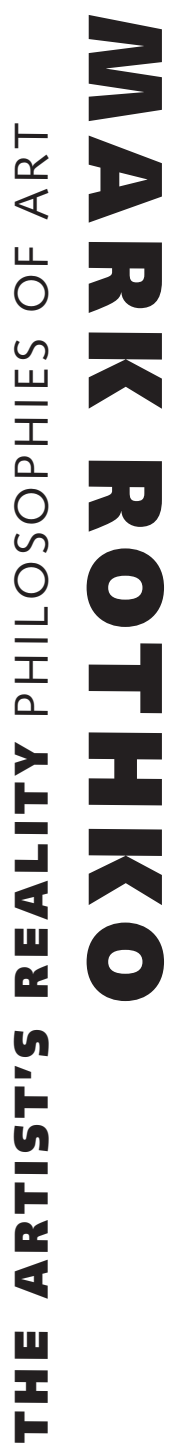


Writings by Mark Rothko

(C)2004 Kate Rothko Prizel and Christopher Rothko

Paintings by Mark Rothko

C)1998 Kate Rothko Prizel and Christopher Rothko

Paintings and drawings on paper by Mark Rothko

(C)2004 Kate Rothko Prizel and Christopher Rothko

Introduction @2004 Christopher Rothko

All rights reserved. This book may not be reproduced, in full or in part, including illustrations, in any form (beyond that copying permitted by Sections 107

and 108 of the U.S. Copyright Law and except by reviewers for the public press), without express written permission from the Estate of Mark Rothko.

Designed by Daphne Geismar

Set in Minion and Syntax type by Amy Storm

Printed and bound in the USA by Thomson Shore

Color insert by Thames Printing Company, Inc.

Jacket illustrations: (front) Manila folder with Mark Rothko's handwritten notation "Artists Reality";

(back) Mark Rothko in his studio, 1945-46

Library of Congress Cataloging-in-Publication Data Rothko, Mark, 1903-1970.

The artist's reality: philosophies of art/Mark Rothko; edited and with an introduction by Christopher Rothko.

p. $\mathrm{cm}$.

Includes index.

ISBN 978-0-300-10253-4 (cloth: alk. paper)

1. Rothko, Mark, 1903-1970-Written works. 2. Rothko, Mark, 1903-1970-Philosophy. 3. Painting-Philosophy. I. Rothko, Christopher. II. Title.

ND237.R725A35 2004

$759.13-\mathrm{dc} 22$

2004011574

ISBN 978-0-300-11585-7 (pbk. : alk. paper)

A catalogue record for this book is available from the British Library.

The paper in this book meets the guidelines for permanence and durability of the Committee on Production Guidelines for Book Longevity of the Council on Library Resources.

1098765 
FOR KATE, WITHOUT WHOM THERE WOULD HAVE BEEN NOTHING

$-C R$ 
This page intentionally left blank 